\title{
The Impact of Electrical Power Interconnection Cooperation between West Kalimantan and Sarawak in Increasing Economic Growth Potential in West Kalimantan
}

\author{
Riani Septi Hertini \\ Universitas Muhammadiyah Yogyakarta \\ Email:rianiseptih@gmail.com
}

\begin{abstract}
Electric power is a critical energy source for human life to fulfill the needs of lighting and production processes involving electronic and industrial goods. Indonesia is the country with the largest population in the Southeast Asia region. Thus, electricity demand also increases. The development of uneven electricity infrastructure in Indonesia has made some regions experience limited electrical power. Frequent interruptions and sharing electric power, West Kalimantan is one of Indonesia's provinces with electricity problems since 2006. Almost every day, blackouts occur in several areas, including Pontianak City and surrounding areas. In dealing with this problem, the government's efforts are conducting power interconnection cooperation with Sarawak, Malaysia, geographically bordered directly with West Kalimantan through the ASEAN Power Grid program. In this study, the author will use a qualitative descriptive method by clearly describing the positive impact of the electric power interconnection between West Kalimantan and Sarawak in increasing economic growth potential in West Kalimantan.
\end{abstract}

Keywords: Electric Power Interconnection, ASEAN Power Grid, West Kalimantan, Sarawak, Economic Growth Potential, Paradiplomacy

\section{Abstrak}

Tenaga listrik merupakan sumber energi penting bagi kehidupan manusia untuk memenuhi kebutuhan penerangan dan proses produksi yang menyangkut barang elektronik dan industri. Indonesia merupakan negara dengan jumlah 
penduduk terbesar di kawasan Asia Tenggara. Dengan demikian, kebutuhan listrik juga meningkat. Perkembangan infrastruktur ketenagalistrikan yang tidak merata di Indonesia membuat beberapa daerah mengalami keterbatasan daya listrik. Sering terjadi gangguan dan pemadaman listrik, Kalimantan Barat merupakan salah satu provinsi di Indonesia yang mengalami gangguan listrik sejak tahun 2006. Hampir setiap hari terjadi pemadaman listrik di beberapa daerah, termasuk Kota Pontianak dan sekitarnya. Untuk mengatasi masalah tersebut, pemerintah berupaya melakukan kerja sama interkoneksi tenaga listrik dengan Sarawak, Malaysia yang secara geografis berbatasan langsung dengan Kalimantan Barat melalui program ASEAN Power Grid. Dalam penelitian ini, penulis akan menggunakan metode deskriptifkualitatif dengan mendeskripsikan secara jelas dampak positif interkoneksi tenaga listrik antara Kalimantan Barat dan Sarawak dalam meningkatkan potensi pertumbuhan ekonomi di Kalimantan Barat.

Kata Kunci: Interkoneksi Tenaga Listrik, ASEAN Power Grid, Kalimantan Barat, Sarawak, Potensi Pertumbuhan Ekonomi, Paradiplomacy

\section{INTRODUCTION}

West Kalimantan Province has a direct border with Malaysia, to be precise, Sarawak (East Malaysia). This condition makes West Kalimantan the only province in Indonesia with official access to enter and exit the border area. The land roads have been opened between the two countries as far as $400 \mathrm{~km}$ from Pontianak-EntikongKuching (Sarawak, East Malaysia) and can be reached approximately 6-8 hours of travel. The access is also marked by constructing the National Border Post (PLBN) in
Entikong, West Kalimantan (Kalbar, 2019).

From an economic point of view, West Kalimantan Province still has problems with inadequate infrastructure, lack of competent human resources, and minimal investment or investment from both domestic and foreign (Pontianak Post, 2018) due to the ineffective performance of local governments in overcoming these problems. The investment climate, which is still concentrated in big cities such as the islands of Java, Sumatra, and Sulawesi, has made West Kalimantan 
far from the central government's attention (BPS, 2018).

In terms of economy and welfare on Kalimantan, West Kalimantan still lags behind other provinces, East Kalimantan, Central Kalimantan, and South Kalimantan. The need for investment in improving the economy and welfare of the people in West Kalimantan Province is urgent. However, in attracting investors' interest, all government and society elements must cooperate in evaluating infrastructure, procedures, and permits that facilitate and support investors to create a conducive atmosphere (Bariyah, 2015).

West Kalimantan has quite a large land area, plus land conditions suitable for plantations, especially for oil palm. This condition supports the entry of oil palm investment. The sectors of interest to investors in West Kalimantan are the trade sector and the manufacturing sector (Yuliasih, 2019). With these conditions, it can be advantageous to advance West Kalimantan at the national and international levels. The West Kalimantan government is obliged to have preparations and strategies to establish better infrastructure, especially electricity infrastructure, a crucial economic development element (Bariyah, 2015).

Electric power is a critical energy source for human life in lighting needs and production processes that involve electronic goods and industry. The benefits of electrical energy are enormous. However, the energy sources of electricity generation are minimal and non-renewable. Therefore, in preserving it, strategic steps are needed to meet the needs of electrical energy optimally and affordably (Anray, Tenaga Listrik Sebagai Sumbenting, 2018). Indonesia's limited electrical energy source has made energy security in Indonesia deteriorate in recent years. This issue is due to the inability to fulfill electricity needs, where the need for energy is increasing and is not balanced with the available energy. There are often temporary blackouts and sharing of electrical energy alternately by PT. PLN (Persero). Indonesia's dependence on petroleum as an energy source has resulted in many of Indonesia's regions that have not developed other energy sources. Meanwhile, for low-emission geothermal and solar energy sources, the costs are still high (Natali, 2017). 
West Kalimantan Province still has problems with electricity infrastructure. Since 2006, blackouts have occurred in rotation in several areas such as Pontianak City and its surroundings to the Kapuas Hulu and Border areas. Even the blackout for the Sintang area can be from early morning until the next morning. PLN for the West Kalimantan Region deliberately reduces the use of diesel fuel, whose stock is running low so that the condition of the two power plants owned by PT PLN for the West Kalimantan Region cannot work optimally. Thus, this condition can make Pontianak City and its surroundings threatened with blackout or total blackout (Anray, http://www.alpensteel. com/article/131-225-pemadamanlistrik/1338-masalah-kelistrikandi-kalbar., 2019).

Pontianak City is the highest electricity user in the West Kalimantan region with a capacity of $110 \mathrm{MW}$ and a peak load of 115 MW because it is the center of the regional government, trade, and housing, where all economic centers are located in this city. All industrial, residential, and commercial areas where several feeders are fed will be blackouts in turns within 3 (three) days. The length of blackout time is during the day, starting at 06:00 - 16:00 and 18: 00-22: 00 at night. This condition can be detrimental to small to mediumsized entrepreneurs who are highly dependent on electricity, such as internet cafes, printers, cakes, food, beverages, and large industrial factories to disrupt investment activities and the West's economy Kalimantan (Anray, http://www. alpensteel.com/article/131-225pemadaman-listrik/1338-masalahkelistrikan-di-kalbar., 2019).

In dealing with these problems, the efforts made by the central government in building electricity infrastructure in Indonesia, especially West Kalimantan Province, are by interconnecting electricity with Malaysia, to be precise, the State of Sarawak, which is directly adjacent to West Kalimantan through one of the energy programs in the region. ASEAN, namely the ASEAN Power Grid (APG), believes in the critical benefits of efficient, reliable, and resilient electricity infrastructure in stimulating regional economies and development. Thus, in meeting the increasing electricity demand, large investments in power generation capacity are urgently needed and recognize the potential benefits that can be obtained from the establishment of an integrated system through the APG program under 
the ASEAN Vision 2020 adopted at the 2nd Informal ASEAN Summit in Kuala Lumpur on December 2, 1997. Heads of ASEAN Power Utilities / Authorities (HAPUA) is a particular energy agency tasked with ensuring regional energy security by promoting efficient use and sharing resources (ACE, 2017).

The cooperation in the energy sector is also a form of ASEAN's awareness of Southeast Asia's economic conditions, which continue to develop, accompanied by the diversity of resources owned by member countries. Some ASEAN member countries are exporters and importers of energy, but some countries experience shortages in developing energy resources. This cooperation is an ASEAN effort in creating energy integration in ASEAN (ASEAN, Overview, 2014). Thus, the power interconnection cooperation between West Kalimantan and Sarawak is expected to run proportionately to benefit all parties, especially West Kalimantan, experiencing electrical problems. Another advantage of this cooperation is that it can positively impact the potential for economic growth in West Kalimantan Province so that problems, such as the lack of competent human resources and investment from within the country or foreigners, can be overcome.

\section{THEORY FRAMEWORK AND RESEARCH METHODOLOGY}

In discussing the problems, the author will use a qualitative descriptive method by providing a clear picture of the impact of the interconnection of electricity between West Kalimantan and Sarawak in increasing the potential for economic growth in West Kalimantan by using secondary data such as books, documents, journals, laws, and internet sites. In analyzing the problem, the author will also take advantage of theoretical and conceptual foundations in directing the focus of research following the field's data and conditions.

\section{A. Paradiplomacy Concept}

Paradiplomacy is the behavior and capacity of non-state actors in foreign relations and cooperation to achieve their specific interests. Diplomatic activities, which put full sovereignty to the central government in the formal constitutional element, have now shifted to the emergence of local or autonomous regional participation in international activities. For the first time, the term paradiplomacy was first introduced to an academic debate carried out 
by Basque scientists, Panayotis, Soldatos in the 1980s as a merger of the term 'parallel diplomacy' to 'paradiplomacy', which means 'the foreign policy of non-central,' according to Aldecoa, Keating, and Bayer. The paradiplomacy that Ivo Duchacek has put forward for this concept is' micro-diplomacy (Mukti, 2015).

This paradiplomacy concept also discusses how political politics links to international politics as one of the globalization actors. In his journal Paradiplomacy, Stefan Wolff tried to mediate the argument between realists and transformers. According to Wolff, paradiplomacy indicates that the state retains its full form of sovereignty. However, paradiplomacy is used as a mechanism for the state to prosper its people in utilizing power. Wolff considers that the emergence of international actors is not a threat to the state but a trend in which the state must start sharing its power with local actors. Of course, the state can obtain maximum benefits compared to conventional StateCenti diplomacy (Wolf, 2007).

TheParadiplomacy phenomenon initially occurred in Europe, but at this time, paradiplomacy has become commonplace in the life of transnational societies, including in Indonesia. Many autonomous regions or known as Provincial / District / City governments are actively cooperating with other parties in the form of a Memorandum of Understanding (MoU) or several other forms of international agreements. According to Mochtar Masoed, autonomous regions in the context of paradiplomacy exist in the intersection of domestic affairs and foreign affairs. The linkage of autonomous regions in international relations is their role as actors (Mukti, 2015).

Therefore, autonomous regions have an essential meaning in studying international relations and must be prioritized since autonomous regions can directly establish foreign relations with foreign parties, both government and non-government. In other words, autonomous regions can bypass through the central government (with the power-giving country's provisions). Not only sub-national entities, but these actors can also take the form of tribal groups, economic interest groups, or multinational companies. Paradiplomacy should understand the people so that foreign cooperation can focus on regional development in several sectors. Paradiplomacy is divided into three types (Santos, 2015): 
1. Transborder paradiplomacy

The diplomacy process by sub-state actors who have direct geographic borders

2. Transregional paradiplomacy

The diplomatic process by sub-state actors from different countries, but one region

3. Global paradiplomacy

The diplomatic process by sub-state actors in different regions

Of the three types of paradiplomacy, the interconnection cooperation between West Kalimantan and Sarawak's provinces is included in Transborder Paradiplomacy, where the diplomacy process can be carried out the two regions are geographically direct borders. With such conditions, of course, it can benefit one another.

Meanwhile, according to Lecour's view, paradiplomacy activities are a continuation of the history of integration in each country and can be categorized into 3 (three) (Lecours, 2008):

1. Paradiplomacy is an economic objective, such as expanding the market for developing investment to foreign countries and mutual investment. This relationship does not include the transnational interactions' political elements and is commonly done in the United States and Australia.

2. Paradiplomacy is for some cooperation or multi-purposes between economy, culture, education, health, technology, etc. The type of cooperation or multi-purposes is between economy, culture, education, health, technology, etc. This type refers to a decentralized international cooperation model. Various provinces in several countries such as Germany, Africa, Vietnam, and Poland apply this paradiplomacy.

3. Complex diplomacy in including political motives and a specific regional nationalist identity by conducting foreign cooperation with high enthusiasm to show a specific regional, national identity, and autonomous and different from some regions in their country, countries do Paradiplomacy activities include Belgian Flanders, Catalonia-Spain, Quebec-Canada, and the Basque Country.

Of the three groups above, the implementation of foreign cooperation by the local government or paradiplomacy in Indonesia can 
be included in the second category where the local government visits foreign parties using an MoU or what is done by Kalimantan province and Sarawak.

\section{B. Economic Growth Theory}

Economic growth is one indicator of successful development in a regional economy, determined by high growth, indicated by national output changes, using the Gross Regional Domestic Product (PDRB) region (Adisasmita, 2013). Economic growth can also be defined as the growth of people's economic activities that can increase goods and services or increase national income. Economic growth is a process of changing a country's economy on an ongoing basis towards better conditions over a certain period (Adisasmita, 2013).

A critical factor in encouraging the growth of a country's economy is adequate infrastructure development. Economic growth affects people's welfare. It can provide new job opportunities and reduce unemployment. The growth of a country's economy can simultaneously stimulate an acceleration so that development can occur evenly (Angelina, 2019).

According to Kuznets, economic growth is when a country's capacity in the long-run increases in supplying its population's economic needs. The increase in capacity is due to technological, institutional, and ideological advances regarding the existing demand conditions (Ahmad Ma'aruf dan Latri Wihastuti, 2008).

Economic growth theory is classified into two: classical economic growth theory and modern economic growth theory. The classical economic growth theory is a theory coined by economists such as Adam Smith, David Ricardo, and W.A Lewis. In classical economic theory, analysis is based on the belief in the effectiveness of freemarket mechanisms. Meanwhile, modern economic growth theory has essential characteristics that acknowledge the government's important role in dealing with the free market system's failure. This theory sees that government interference will make the free market system more effective (Quipper, 2019).

One of the modern economic growth theories is the HarrodDomar theory of economic growth. Domar argues that this theory is a development theory from the shortrun Keyness theory to a long-term macro theory, assuming investment expenditure does not affect 
aggregate demand, but on aggregate supply experiences an influence on production capacity. In a broader view, the investment will increase capital stock to boost people's ability to produce output. The output is a potential that can be generated from the existing capital stock (Ahmad Ma'aruf dan Latri Wihastuti, 2008).

Economic growth is also influenced by natural resources, the number, and quality of population education, science and technology, social systems, and markets. The openness of a country's economy will have a positive impact on growth. The economy of a country integrated with the global economy has more opportunities to expand the market and increase competitiveness to achieve efficiency. Indonesia was an open economy during the New Order. The Indonesian economy was integrated with the world, so export and import activities were drivers of growth. International cooperation activities carried out by regional governments on the border integrated with other countries can also provide opportunities and opportunities to improve people's welfare. Fewer areas of power will facilitate appropriate and effective policies and decisions to increase GDP per capita (Ahmad Ma'aruf dan Latri Wihastuti, 2008).
In this research, the international cooperation between West Kalimantan and Sarawak in the development of electricity infrastructure is expected to positively impact both regions. The electricity export-import activities carried out are proof of infrastructure development and can improve the investment climate to boost the regional economy, especially for West Kalimantan Province.

\section{RESULT AND DISCUSSION}

ASEAN believes that the primary function of electricity infrastructure is efficient, reliable, and resilient in stimulating regional economic development and improvement. Large investments in power generation capacity are required To meet the growing electricity demand. In recognizing the potential benefits that can be obtained from the establishment of an integrated system, ASEAN establishes electricity interconnection arrangements in the region through one of the programs under the ASEAN Center for Energy (ACE) called the ASEAN Power Grid (APG) under the ASEAN 2020 vision adopted at the 2nd ASEAN Informal Summit in Kuala Lumpur on December 15, 
1997. Development of the APG was first carried out based on bilateral cross-border requirements, then expanded to a sub-regional basis, and finally to a total integrated regional system. It is expected to increase cross-border trade in electricity, which will provide benefits in meeting electricity demand and improving energy services in the region (ASEAN, 2019).

Heads of ASEAN Power Utilities / Authorities (HAPUA) is a power organization (Specialized Energy Body) recognized in the Southeast Asia region. HAPUA was founded in 1981. A Memorandum of Understanding was signed in May 2004 by the Department of Electricity Services Brunei Darussalam, Electricité du Cambodge from Cambodia, PT PLN (Persero) Indonesia, Electricité du Laos from Laos, Tenaga Nasional Berhad Malaysia, Ministry of Electricity Myanmar, National Power Philippines Corporation, Singapore Power Limited Singapore, Thailand Power Generation Authority, and Vietnam Electricity. It aims to promote cooperation among its members to strengthen regional energy security through developing interconnections, increasing private sector participation, encouraging equipment standardization, promoting joint project development, cooperation in human resources, research, development, and improving quality and reliability of power supply system (HAPUA, 2016)

APG is a project instructed by the Head of the Government / ASEAN member countries to achieve ASEAN economic integration, namely creating a regional economic area that is highly competitive in the fields of infrastructure development, energy cooperation, ICT, and SME development, at the 17th AME meeting in Bangkok on July 1997 which later issued the APAEC 1999 - 2004 document covering the implementation of the APG program. The energy ministers of each country signed an $\mathrm{MoU}$ in March 2007 to strengthen member countries' cooperation in developing and increasing energy availability in the region (Said, 2019).

This cooperation utilizes every primary source, a single-use electrical energy source such as coal, natural gas, and petroleum, to provide electrical energy based on a power plant construction project in predetermined cooperation. APG is also a collaboration that allows other countries with more 
electrical energy sources to transfer their electricity to other countries. Through this APG interconnection project, the government seeks to improve electricity security in remote areas and Indonesia's border areas. Indonesia has ratified the APG MoU in Presidential Decree Number 77 of 2008 concerning the APG MoU Ratification (Said, 2019).

The ASEAN region has abundant energy resources with excellent hydropower potential. It provides an excellent opportunity to efficiently use available energy resources in the ASEAN region, reducing the need for and independence on imported fuels from other regions. An adequate and reliable electricity supply is essential for the economic development of ASEAN member countries. To continue to be reliable and meet the demand for electrical energy, investment capital to install additional generating capacity and transmission lines is needed. This condition shows that lowering the investment capital requirements is by connecting the power system through the ASEAN member countries (ASEAN, 2016).

APG cooperation by Indonesia and Malaysia includes 3 (three) projects: (ASEAN, 2016):

1. The Sarawak-West Kalimantan project
2. The Sumatra-Peninsular Malaysia Project

3. The Sabah-North Kalimantan project

Each of the two countries' leaders between Indonesia and Malaysia had a meeting and discussion before the interconnection. The Indonesian Minister of Energy and Mineral Resources and the Minister of KeTTHA Malaysia in Jakarta on June 26, 2015, agreed to form a technical committee to carry out the project. Sudirman and Panglima Maximus also signed the Joint of the Acceleration of The Implementation of Power Interconnection Projects between Indonesia and Malaysia during the Earth-Centered-EarthFixed (ECEF) meeting on February 12, 2016, in Putrajaya (EDSM, 2916).

Of the three collaborations between Indonesia and Malaysia above, currently, the project between West Kalimantan and Sarawak is already operating. This development cooperation was endorsed by signing an agreement between PLN Planning Director Nasri Sebayang with SEB Chief of Executive Officer Mr. Torstein Dale Sjoweit in Jakarta in July 2011. Second Minister of Planning and Resources Management \& Minister of Public Utilities State of Sarawak 
The Honorable Datuk Amar Hj Awang Tengah Ali Hasan was the witness for the contract's signing to construct this interconnection network. The points of cooperation between the two power companies were listed in Term Sheets of West Kalimantan-Sarawak Power. The interconnection cooperation between the two regions was carried out by the two countries' national electricity companies. PT. PLN Persero (Perusahaan Listrik Negara) Pusat in Jakarta was the executive agency and PT. PLN for the West Kalimantan as the implementing agency in the field. Meanwhile, Malaysia was assisted by Sarawak Electricity Supply Co. Ltd. (SESCO) under the SEB (ASEAN, 2016).

This interconnection cooperation between West Kalimantan and Sarawak is a form of diplomacy or foreign cooperation called paradiplomacy. Paradiplomacy comes from the behavior and capacity in carrying out foreign cooperation by sub-state or nonstate actors, towards their specific interests. In this case, Indonesia and Malaysia are not the main domestic actors, but the national electricity companies of the two countries, which are then delegated to regional branches as implementing agencies in the field, namely West Kalimantan and Sarawak as outlined in the form of Term Sheets of West KalimantanSarawak Power. The Indonesian government works with Malaysia to build an interconnection project for the West KalimantanSarawak power grid through a 275 VK SUTET between GITET Bengkayang (PT.PLN Kalimantan Barat) and GITET Mambong (SEB Malaysia) as far as $122 \mathrm{~km} .86$ $\mathrm{km}$ of transmission networks are in West Kalimantan, and $35 \mathrm{~km}$ are in the Sarawak area, with 345 towers (Pangaribuan, 2016). Two hundred one towers were installed in Indonesia's transmission system (from GITET Bengkayang to the border). Meanwhile, 144 countries are located in the Sarawak region, Malaysia (from GITET Mambong to the border). Together, these transmission lines in the two countries form the first BIMPRegional as EAGA's flagship project and the Trans Borneo power grid's first Leg (Pangaribuan, 2016).

The interconnection project between West Kalimantan and Sarawak was connected on January 20, 2016. SESCO would import power to PT. PLN Persero (State Electricity Company) West Kalimantan region of 50 megawatts (MW) in stages. During the first interconnection on January 20, 2016, 
the connected energy was $20 \mathrm{MW}$. On May 9, 2016, it increased to 70 $\mathrm{MW}$, then increased to $90 \mathrm{MW}$, and would increase to $230 \mathrm{MW}$ during peak load times. This cooperation refers to the PEA Agreement, where PT PLN and SESCO agreed to do the export-import of electric power. SESCO's electricity supply would address the power shortage in the West Kalimantan region. Malaysia imported electricity to PLN West Kalimantan to overcome blackouts in the West Kalimantan region, especially in the Equatorial system, in the last two years before connecting this interconnection (Duta, 2016).

This electricity import also restored the West Kalimantan PLN Fuel Mix with savings of up to Rp. 3.5 billion per day. This cooperation re BPP costs from the previous Rp. 2,700 to Rp. 1,700 per kWh. The buying and selling price between PLN and SESCO has also been agreed to be Rp. 900 per $\mathrm{kWh}$ without any increase. Payment is made in the form of Malaysian Ringgit according to the agreement of both parties. It is more profitable when compared to using United States dollars. This cooperation is the first electricity cooperation for PT. PLN as well as for SESCO Malaysia. The term of the interconnection cooperation between PLN and SESCO is divided into two cooperation facilities, namely (ESDM, 2016):

a. First phase (5 years):

In the first phase, PT PLN in the West Kalimantan region imported electricity from SESCO through the take and pay scheme, from $50 \mathrm{MW}$ during Peak Load Time (LWBP) and 230 MW during Peak Load Time (WBP) and would increase incrementally and pay according to the amount of power imported.

b. Second phase (15 years):

In the second phase, both parties mutually exported and imported electric power according to the agreed capacity or in the take or pay scheme. In the second phase of this collaboration, PLN and SESCO would also mutually import and export electric power based on the two electric power systems' economics or economic exchange power transfers using the day-head agreement principle. This principle meant an agreement a day before the power transfer and depended on the two systems' operating conditions. 
In obtaining an energy source, Sarawak produced it through a hydroelectric power plant (PLTA) from a large dam in Sarawak's Sabar area. The dam could produce around 6000 MW. With this electricity import, Indonesia would benefit greatly. Before its connection with the Sarawak network, West Kalimantan had only reached 150 MW with an electrification ratio of $57.54 \%$, even though West Kalimantan's economy experienced development with the palm oil industry and also the smelter at that time (IESR, 2013).

With the interconnection cooperation carried out, the electricity condition in West Kalimantan Province has increased with an increase in the capacity of $400 \mathrm{MW}$ so that the surplus is more than 100 MW. These conditions make electricity in West Kalimantan no longer occur in rotation, let alone threatened with the blackout. In the sale of electrical energy by PT PLN in the West Kalimantan region, several customers are social, household, business, industrial, factory, and multi-purpose. In 2016, the six customer groups saw a significant increase, especially in industrial and factory groups. With a surplus of energy in the West Kalimantan system, it provides opportunities for investors who want to invest in West Kalimantan so that they require a large amount of electrical energy, such as the bauxite mining industry, which requires electricity as a continuity in the production process, so there is no need to build their power plants (BPS, 2015).

Masuknya para calon pelanggan baru tersebut, tentunya memberikan dampak bagi masyarakat sekitar dengan terbukanya lapangan pekerjaan baru sehingga dapat menurunkan angka pengangguran dan meningkatkan angka produksi barang dan jasa yang tentunya akan menambah pendapatan daerah dan meningkatkan potensi pertumbuhan ekonomi di Kalimantan Barat. Hal tersebut ditandai dengan meningkatnya laju pertumbuhan ekonomi di Kalbar di tahun 2016 sebesar 5,20\%, dibandingkan tahun sebelumnya yang hanya 4,81\% (Maskartini, 2017). Kota Pontianak merupakan ibukota provinsi yang menyumbangkan angka PDRB terbesar. PDRB Kalimantan Barat didukung oleh lapangan-lapangan usaha yang ada di Kalbar, seperti sektor lapangan usaha pertanian, kehutanan, dan perikanan. Ketiga sektor lapangan usaha tersebut tentunya sangat dipengaruhi oleh ketersediaan listrik yang tersedia di Kalimantan 
Barat bagi para pengusaha industri tersebut (BPS, 2019).

\section{CONCLUSION}

The West KalimantanSarawak interconnection project aims to support investment in strategic transmission assets linking international boundaries to optimize the power grid by reducing the overall requirement for spare capacity, increasing system reliability, eliminating transmission bottlenecks, and transmitting less expensive power from another area, dealing with regional socioeconomic and environmental improvement. Under this project, Sarawak exports additional electricity to West Kalimantan, which will generate additional revenue for Sarawak Energy Berhad (SEB). On the other hand, the power system improves the quality and reliability of the power supply. It helps to diversify the portfolio by stopping old, inefficient plantbased oil-based power in West Kalimantan, thereby reducing $\mathrm{CO} 2$ emissions on the Indonesian Island of Borneo. This project will support the potential development of noodles for the West Kalimantan region in the long term.

\section{BIBLIOGRAPHY}

ACE. (2017). ASEAN Power Grid. Retrieved Februari 9, 2019, from ASEAN Center For Energy: http://www.aseanenergy.org/ programme-area/apg/

Adisasmita, R. (2013). TeoriTeori Pembangunan Ekonomi, Pertumbuhan Ekonomi, da Pertumbuhan Wilayah. Yogyakarta: Graha Ilmu.

Adosasmita, R. (2013). TeoriTeori Pembangunan Ekonomi, Pertumbuhan Ekonomi dan Pertumbuhan Wilayah. Yogyakarta: Graha Ilmu .

Ahmad Ma’aruf dan Latri Wihastuti. (2008). Pertumbuhan Ekonomi Indonesia: Determinan dan Prospeknya. Jurnal Ekonomi dan Studi Pembangunan Vol.9, No.1 , 44-55.

Angelina, C. (2019). Teori Pertumbuhan Ekonomi. Retrieved Oktober 2019, 22, from Kompasiana : https:// www.kompasiana.com/181 910501059 callistaa/5d99c0 $3 \mathrm{e} 0 \mathrm{~d} 82303$ fee05a622/teoripertumbuhan-ekonomi

Anray. (2019). http://www. alpensteel.com/article/131225-pemadaman-listrik/1338masalah-kelistrikan-di-kalbar. Dipetik Mei 26, 2019, dari 
Alpen Steel: http://www. alpensteel.com/article/131225-pemadaman-listrik/1338masalah-kelistrikan-di-kalbar

Anray. (2018). Tenaga Listrik Sebagai Sumbenting. Retrieved Nei 21, 2019, from Alpen Steel : http://www.alpensteel. com/article/126-113-energilain-lain/2383--tenaga-listriksebagai-sumber-energi-yangpenting

ASEAN. (2019). ASEAN Power Grid. Dipetik April 2019, 20, dari ASEAN Center For Energy: http://www.aseanenergy.org/ programme-area/apg/

ASEAN. (2019). ASEAN Power Grid. Retrieved April 22, 2019, from ASEAN Center For Energy: http://www.aseanenergy.org/ programme-area/apg/

ASEAN. (2014). Overview. Retrieved Februari 25, 2019, from ASEAN Secretariat: http://www.asean.org/asean/ about-asran/overview

ASEAN. (2018). The Evolution of Electricity Trades in Indonesia. Retrieved Agustus 8, 2019, from ASEAN Center For Energy: http://www.aseanenergy.org/ blog/the-evolution-\%20 ofelectricity-trades-in-asean/\%20 diakses\%20pada\%202-04-\%20 2018

ASEAN. (2016). West KalimantanSarawak Power Interconnection BIMP-EAGA. Retrieved aGUSTUS 9, 2019, from ASEAN Secretariat: file:///C:/ Users/user/Downloads / West_Kalimantan_-_Sarawak_ Power_Interconnection BIMP_-_EAGA\%20(1).pdf

Bariyah, N. (2015). Analisis Indikator Fundamental Ekonomi Daerah di Kalimantan Barat: Pertumbuhan Ekonomi, Pendapatan Perkapita dan HDI. Jurnal Ekonomi Bisnis dan Kewirausahaan Vol.4 No.1 , 77-93.

BPS. (2018). Jumlah Penduduk Provinsi Kalimantan Barat Menurut Kabupaten/Kota dan Jenis Kelamin. Dipetik Februari 8, 2019, dari BPS Provinsi Kalimantan Barat: https://kalbar.bps.go.id/ statictable/2018/02/26/125/ jumlah-penduduk-provinsikalimantan-barat-menurutkabupaten-kota-danjen is-kelamin-sensuspenduduk-2010.html

BPS. (2015). Penjualan Tenaga Listrik Menurut Kelompok Pelanggan 2004-2007. Retrieved September 13, 
2019, from BPS Kalimantan Barat: https://kalbar.bps.go.id/ statictable/2019/02/11/130/ penjualan-tenaga-listrikm e n u r u - k el o m p ok pelanggan-2004-2017-kwh-. html

BPS. (2019). Seri 2010, Produk Domestik Regional Bruto Tahunan Menurut Usaha Provinsi Kalimantan Barat. Retrieved Oktober 5, 2019, from BPS Kalimantan Barat: https://kalbar.bps.go.id/ dynamictable/2018/03/20/87/seri-2010-produk-domestikregional-bruto-kalimantanbarat-menurut-lapanganusaha-atas-dasar-hargaberlaku-2010-2018-jutarupiah-.html

Duta, D. K. (2016). iNDONESIA MULAI IMPOR IISTRIK dARI mALAYSIA. Retrieved aGUSTUS 9, 2019, from cnn iNDONESIA: https:// www.cnnindonesia.com/ ekonomi/20160121202944-85 - 105934/indonesia-mulaiimpor-listrik-dari-malaysia

EDSM, K. (2016). Liputan Khusus Dirjen Ketenagalistrikan Kementrian ESDM Dirjen Ketenagalistrikan Edisi 47, Vol.12. Retrieved Seotember 4, 2019, from Dirjeb
Ketenagalistrikan ESDM : http://www.djk.esdm.go.id/ pdf/Buletin/Buletin\%20 Ketenagalistrikan \% 20 No.53\%20Vol.14\%20Maret\%20 2018.pdf

ESDM, K. (2016). Mengenal ASEAN Power Grid . Retrieved aGUSTUS 9, 2019 , from Kementrian ESDM : http:// www.djk.esdm.go.id/index. php/detail-berita?ide $=4119$

HAPUA. (2016). About HAPUA . Retrieved April 22, 2019, from HAPUA Secretariat : http:// hapua.org/main/hapua/about/ IESR. (2013). Miris, PLN Lebih Pilih Impor Listrik Dari Malaysia . Retrieved Agustus 9, 2019, from IESR : http://iesr.or.id/ miris-pln-pilih-impor-listrikdari-malaysia/

Kalbar, P. (2019). Gambaran Umum: Aspek Geografis. Dipetik Februari 5, 2019, dari Pemprov Kalimantan Barat: http://kalbarprov.go.id/info. php?landing $=2$

Lecours, A. (2008). Political Issues of Paradiplomacy: Lessons From The Develop,emt World. Netherlands Indtitute of International Relations'Clingendael', 1. 
Maskartini. (2017). Ekonomi Kalbar Tumbuh, Nerikut Lapangan Usaha Penyumbang PDRB. Retrieved Oktober 9, 2019, from Tribun Pontianak: https://pontianak.tribunnews. com/2017/02/06/ekonomikalbar-tumbuh-berikut lapangan-usaha-penyumbangpdrb

Mukti, T. A. (2015). Paradiplomacy: Bangkitnya Aktor Lokal di Fora Internasional. The Politics: Jurnal Magister Ilmu Politik Universitas Hasanudin, Vol.1, No.1 , 85-86.

Natali, G. (2017). Kompas. com. Retrieved Februari 8, 2019, from Energi Baru Terbarukan Menjadi Kunci Ketahanan Energi Indonesia: https://money.kompas.com/ $\mathrm{read} / 2017 / 07 / 20 / 214402626 /$ energi-baru-terbarukanmenjadi-kunci-ketahananenergi-indonesia?page $=$ all

Pangaribuan, M. (2016). RI-Malaysia Kerjasama Interkoneksi Listrik Antar Negara. Retrieved 8 2019Agustus, from Satuharapan.com : http:// www.satuharapan.com/readdetail/read/ri-malaysia-kerjasama-interkoneksi-listrikantarnegara
Quipper. (2019). Pertumbuhan Ekonomi . Retrieved Aoruk 2019 , 16, from Quipper.com : https://www.quipper.com/ id/blog/mapel/ekonomi/ pertumbuhan-ekonomi/

Said, A. (2019). Kerjasama ASEAN Power Grid Dalam Meningkatkan Ketahanan Listrik di Indonesia. jom fISIP vO;.5, eDISI ii , 1-11.

Santos, M. (2015). Perkembangan Para Paradiplomasi dalam interaksi Internasional. Retrieved Februari 12, 2019, from Poesi Ilmu.com: https:// www.porosilmu.com/2015/12/ $\mathrm{m} \mathrm{e} \mathrm{m} \mathrm{a} \mathrm{h} \mathrm{a} \mathrm{m} \mathrm{i} \mathrm{-} \mathrm{k} \mathrm{o} \mathrm{n} \mathrm{s} \mathrm{e} \mathrm{p} \mathrm{-}$ paradiplomasi-dalam.html

Wolf, S. (2007). Paradiplomacy. The Bologna Center Journal of International Affairs, Vol.10, 7. Yuliasih, F. W. (2019). Pengaruh Pertumbuhan Ekonomi, Inflasi, dan Pendidikan terhadap Tingkat Pengangguran dan Kemiskinan di Provinsi Kalimantan Barat. Jurnal Ekonomi Daerah Vol.7 No.1 . 